Volume 11 Number 4, October-December 2017: pp. 317-327

. Copyright (c) 2017 FIAT JUSTISIA. Faculty of Law, Lampung University, Bandarlampung, Lampung, Indonesia. ISSN: 1978-5186 | e-ISSN: 2477-6238.

Fiat Justisia is licensed under a Creative Commons Attribution 4.0 International License, which permits unrestricted use, distribution, and reproduction in any medium, provided the original work is properly cited.

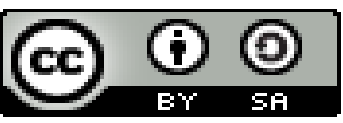

\title{
The Law Enforcement Against the Criminal Acts of Destruction of Crops
}

\author{
Eddy Rifai \\ Faculty of Law, University of Lampung \\ eddyrifai63@gmail.com
}

\begin{abstract}
This research uses a normative juridical approach to study the law enforcement against the criminal acts of destruction of crops, about the regulation on the Civil and Agrarian Law. The research approach uses a normative juridical approach that is based on legislation, theories, and concepts related to writing research. The result of the research asserts that the law enforcement against the criminal acts of destruction of crops based on the judges of the Supreme Court Decision No. 1909 K / Pid / 2010, using the viewpoint of Agrarian Law to the principle of horizontal separation asset that the holders of rights to land only control the extent of its surface, while the building or anything inherent in the land have different ownership rights to its land. The criminal law enforcement using viewpoint of Law No. 5 Of 1960 Regarding The Basic Regulations On Agrarian Principles (UUPA) did not need to prove the ownership of the land between the two conflicting party but to prove who the owner of the destroyed crops is. If the plant grows the property of the complainant party then the reported person will meet the elements as perpetrators of criminal acts in the Article 406 paragraph (1) of the Criminal Code. However, by using the legal basis of the Law Number 51 PRP of 1960 on Prohibition to Using the Land without Obtaining the Permission from the Owner of the Land or the Authorized Person (the "Law No 51 PRP/1960"), landowners can maintain proprietary rights and submit the case to the legal process procedure, hence it does not need to happen that the crop destruction by the owner of the land will be entangled in criminal law pursuant to the Article 406 paragraph (1) Criminal Code.
\end{abstract}


Keyword: Law Enforcement, The Criminal Acts, The Destruction of Crops.

\section{A. Introduction}

The Land law recognizes two kinds of principles regarding the land that gives effect in the form of the authority and the ownership of the land. The first principle is known as the principle of attachment (acessie) which means that the soil is not confined to the earth's surface, but also what is under and on top of it because the whole is a unity that is inherent and cannot be separated. ${ }^{1}$ What this definition grants the owners of land rights, the authority and the right to land ownership is not just limited to the soil surface only, but also contained underneath also attached and stand on it. The second principle is the principle of horizontal separation. In this principle, the definition of land only covers the soil surface, hence what is inherent or stand on it and what is contained below is not a single entity but separate forms. ${ }^{2}$

Holders of rights to land are only limited control of the soil surface, while the building or anything inherent has different ownership rights and it opens to the possibility that the holders of such objects attached on the ground are different from that land titles. Everything like a plant or a building that stands on the ground when referring to the Civil Code, all plants or buildings that become part of the soil because it applies the principle of attachment by Article 500 and Article 506 of the Civil Code. It becomes different when referring to the land law as stipulated in the Law No. 5 Of 1960 Regarding The Basic Regulations On Agrarian Principles (UUPA) that applies is the principle of horizontal separation, namely the separation between the land and everything that stands on it. In this case, the effect that the party who plant crops or build a building is as the owner of the plant or the building. By the horizontal separation principle, hence the person who owns the land does not necessarily have anything on that land. The landowner should not assume that the plants or existing buildings on the land itself belong to the landowner.

The history of the land and its rights in the regulation of land before 1960, Indonesia has a duality in the field of land law as a legacy of the Dutch colonial era. At that time, there was a class division based on the division of population groups. Class European and Foreign Orientals subjected to the provisions of Book II BW containing about legal principle of attachment (acessie) as stipulated in Article 500, Article 506 and Article 507 BW, while the indigenous groups applied the customary law which enforced the principle of separation horizontal. ${ }^{3}$ The principle of horizontal separation

\footnotetext{
${ }^{1}$ Boedi Harsono, Hukum Agraria Indonesia, Jakarta: Djambatan, (2003), p. 20

${ }^{2}$ Ibid.

${ }^{3}$ Soepomo, Sejarah Politik Hukum Adat, Jakarta: Djambatan, (1964), p. 85
} 
adopted by the customary law was later adopted in Indonesian land law embodied in the establishment of Law No. 5 Of 1960 Regarding The Basic Regulations On Agrarian Principles referred to as the basic agrarian law. ${ }^{4}$

The principle of the law of the land changes its regulation, after the regulation of the basic agrarian law, regarding the principles of attachment vertical and horizontal separation principle. Vertical attachment principle, which asserts that any ownership automatically plots also prove the ownership of everything that is in it, such as buildings, trees, etc. This principle which is adhered on the Book II of the Civil Code provides that proof of the ownership of the land as well as a proof of the ownership of everything that is on it, until the time of regulation of the basic agrarian law. The principle of vertical attachment turns into horizontal separation principle, which is the principle of ownership separation of the land with everything that is on it. Thus evidence of land rights will not necessarily become proof of the ownership of everything that exists on the ground.

The formation of the basic agrarian law is also a unification in the field of agrarian law, hence it puts an end to dualism in land law to establish the customary law as the basis of the establishment of land law in Indonesia as asserted in Article 5 of the basic agrarian law, which asserts that: "the Agrarian Law which applies to the earth, water, and space is legal custom and does not contradict national interests and the state, which is based on the unity of the nation, with socialism Indonesia as well as with the regulations set forth in this law and other laws, everything with regard to the elements that rely on religious law. The Customary law has been chosen as the basis of legal arrangement Indonesian land because the customary law which is the original law of the Indonesian people have lived and formed from the development of indigenous people of Indonesia. ${ }^{5}$

By Article 5 of the basic agrarian law above, it is known that the customary law is not purely customary law. Since the customary law should not be contrary to the national interest and the country listed in the other laws. The basic agrarian law regulates that the principle used in land law in Indonesia is a principle of horizontal separation in Article 4 paragraph (2) which asserts that the Rights of the land referred to in paragraph (1) of this article confers the authority to use the land, hence the land and water as well as space on it, for the interests that directly relates to the use of land within the boundaries according to this law and other higher legal regulation. The principle of horizontal separation is a principle that divides, limits, and

\footnotetext{
${ }^{4}$ Maria S.W. Sumardjono, Kebijakan Pertanahan (Antara Regulasi dan Implementasi), Jakarta: Kompas, p. 28

${ }^{5}$ Maria S. Sumardjono, Tanah dalam perspektif hak ekonomi, sosial, dan budaya, Jakarta: Kompas, (2008), p. 58
} 
separates the ownership of a land plot and also follows everything concerning the ground horizontally. ${ }^{6}$

The enforcement of the principle of horizontal separation in Indonesian land law provides separation between the ownership of land which is not attached underneath and above these. Hence it is only directly related to the use of land that can be exploited. This limits the authority of the owner of land rights in the use of land he owned, hence the use of what is contained in the ground and attached to it must be proven that it is only about the use of the land. In practice, the law enforcement against the criminal acts of destruction of crops related to land ownership raises a different law enforcement practice.

The Law enforcement that uses the optical viewpoint of Civil Code states that the owner of the land is the owner of growing crops, while the law enforcement that uses of the basic agrarian law states that the landowner is not automatically the owner of the crops. Being an example is the case of Police Report Number: LP / B-420 / XI / 2016 / LPG / RES WK / IFMS, dated November 01, 2016, the destruction of crops on the form of the rice plant belonging to WAYAN JANE and NYOMAN TANGKAS on the area of 18,000 square meters in Way Kanan Regency, Lampung Province, conducted by suspect namely JIRAN Bin PATOK, was hijacking by using tools such as hand tractor to destroy the rice crop. The act of JIRAN bin PATOK which destroys the rice crop based on the command of person namely RR (alias) and based on the letter of assignment from RR which owned the statement of claim for de facto possession of land (sporadic) dated March 30 2015, Land Owners Statement dated March 30, 2015 and the Notice of Inspection Land and village elders Statement dated March 30, 2015 while the rights owned by WAYAN JANE bin SARIE is also the statement of claim for de facto possession of land (sporadic) dated January 28, 2013.

Based on the chronology above, the case may constitute the crime of destruction of goods pursuant to the Article 406 paragraph (1) of the Criminal Code which asserts that "the person who with deliberate intent and unlawfully destroys, damages, renders useless or mislays property which wholly or partially belongs to another, shall be punished by a maximum imprisonment of two years and eight months or a maximum fine of three hundred rupiahs". The legal problem related to the owners of the goods defined as "which wholly or partially belongs to another," which must be proved regarding the ownership of the goods. Whether the complainant

\footnotetext{
${ }^{6}$ Boedi Harsono, Hukum Agraria di Indonesia; Sejarah dan Pembentukan Undang-Undang Pokok Agraria; Isi dan Pelaksanaannya, Jakarta: Djembatan, (1997), p. 50
} 
belongs to Wayan Jane and Nyoman Tangkas or belongs to the suspect Jiran bin Patok, or RR and OOT.

The criminal law enforcement using the optical viewpoint of Civil Code will first prove the ownership of crops in the rice based on the ownership of land, which each of the Rights is based on the statement of claim for de facto possession of land (sporadic). Hence it should have the decision of a civil court to determine the rightful owners and the owners of plants. The Criminal law enforcement using the optical viewpoint of Basic Agrarian Law does not need to prove the ownership of the land between the two parties, but it needs to prove the ownership of the damaged plants. If the plant grows on the property of the defendant, hence it will meet the reported criminal under the Article 406, paragraph (1) of the Criminal Code. Further problems arise related to the legal protection of legitimate landowners to use land by parties who do not have rights. Based on the above description, the problems in this research could be seen as follows: 1) how does the law enforcement stand against the criminal acts of destruction of crops? And 2) How is the legal protection of the legitimate landowners regarding the use of land by unauthorized parties?

\section{B. Research Method}

The type of this research is descriptive, analytical research that seeks to describe and elaborate the issues relate to the law enforcement against the criminal acts of destruction of crops. The approach used is a normative juridical approach that is based on legislation, theories, and concepts related to writing research.

\section{Discussion}

\section{The Law Enforcement Against the Criminal Acts of Destruction of Crops}

The enforcement of criminal law is an attempt by the law enforcement officials by the laws and regulations in performing basic tasks and functions within the criminal justice system. The enforcement of The criminal law as asserted by Barda Nawawi Arief in Heni Siswanto is the overall activity of the executive law enforcement towards upholding the law, justice and the protection of human dignity, order, peace and the rule of law by the 1945 Constitution. ${ }^{7}$ The existence of the process of criminal law enforcement in crime prevention is very important, this aspect is implicitly stated in Criminology 3rd Seminar 1976 which states that: "The criminal law is to be preserved as one of the means of social defense in the sense of protecting the

\footnotetext{
${ }^{7}$ Heni Siswanto, Rekonstruksi Sistem Penegakan Hukum Pidana Menghadapi Kejahatan Perdagangan Orang, Semarang: Pustaka Magister, (2013), p. 1
} 
public from crime by restoring and returning the maker without reducing the balance of the public interest." process to the establishment of the function of legal norms is significantly used as a guide actor in the legal relationship life of the society and the state. The term of law enforcement, according to Andi Hamzah is often mischaracterized as if they were engaged in criminal law or only in the field of repression. The term of law enforcement includes both repressive and preventive. ${ }^{9}$ The law enforcement, according to Barda Nawawi Arief, is associated with four (4) aspects of the protection of society, namely:

a. People need protection against acts that damage and danger to society.

b. People need protection against the dangerous nature of a person.

c. People need protection against the abuse of sanctions of law enforcement and society in general.

d. People need protection for the balance and the value which is disturbed due to the crime. ${ }^{10}$

The law enforcement according to Sudarto is a concern and cultivation acts against the law which happened (onrecht in actu) or tort that may occur (onrecht in potentie). ${ }^{11}$ As a process that is systemic, hence the criminal law enforcement manifest themselves as the application of the criminal law which involve a variety of structural sub-systems such as the police, prosecutors, courts and correctional and included therein is legal counsel. The concrete law enforcement of concrete can be interpreted as a positive force of law in practice as it should be obeyed. Therefore, the provision of justice in a case that is decided by law is significantly and concretely. Law is no more just ideas or concepts that reflect in it and what is called as justice, order and the rule of law as outlined in the form of laws and regulations with the intention to achieve certain goals. Law enforcement is essentially a rule of ideas and concepts into reality. ${ }^{12}$ The enforcement of criminal law in the criminal justice system in principle is oriented to the following aspects:

a. Preventing people from becoming victims of crime.

b. Completing a criminal case so that a community is satisfied that justice has been done and the guilty have been convicted.

\footnotetext{
${ }^{8}$ Lilik Mulyadi, Hukum Pidana, Krimonologi \& Victimologi, Jakarta: Djambatan, (2004), p.30

9 Erna Dewi, Sistem Peradilan Pidana Indonesia (Dinamika dan Perkembangan), Yogyakarta: Graha Ilmu, p. 24.

${ }^{10}$ Barda Nawawi Arief, Tujuan dan Pedoman Pemidanaan, Semarang: Pustaka Magister, (2012), p. 37

${ }^{11}$ Ibid., p. 24

12 Tjong Tjo Djung, Eddy Rifai dan Eko Rahardjo, "Analisis Pemidanaan Terhadap Pelaku Tindak Pidana Perdagangan Orang”, Jurnal Praevia, 6 (2), (2012), pp. 213-214
} 
c. Acting as a prevention therapy so that the offender will not repeat his crimes. ${ }^{13}$

As for the crime of the destruction and damage of objects arranged in a second book Criminal Code, under the Article 406 to Article 412 which regulates crimes contain elements of damage or behavior containing such properties of an object. In Article 406 paragraph (1) asserts that "The person who with deliberate intent and unlawfully destroys, damages, renders useless or mislays property which wholly or partially belongs to another, shall be punished by a maximum imprisonment of two years and eight months or a maximum fine of three hundred rupiahs." The elements regarding with the deliberate intent in Article 406 paragraph 1 apart from the words breaking the law with the word "and." According to Wirjono Projodikoro, this means the actors do not need to know that he was breaking the law by deeds. But he must know that the item belongs to someone else in whole or in part. ${ }^{14}$ The Article 406 has a counterpart in Ned. W.v.S. (The Dutch Penal Code), namely Article 350 which sounds the same, but the penalty of prison a little lighter, i.e., a maximum of two years or a fine of the fourth category. The core part of the offense in Article 406 is as follows:

a. The person who with deliberate intent

b. And unlawfully

c. Destroys, damages, renders useless or

d. Mislays property

e. Which wholly or partially belongs to another ${ }^{15}$

In some specific cases, such as the destruction of the plants associated with the ownership rights to the land and everything on it, the Supreme Court ruled that in the case of destruction of crops, based on the customary law is not necessarily, that the owner of the land itself becomes the owner of the plant that is on top of the land, there are times when the landowner is someone other than the owner of the existing plant on the land. ${ }^{16}$ Referring to the Supreme Court judgment on the decision No. 1909 K / Pid / 2010 stating "That hijacking with bulldozer by the defendant by asking the witness XII: Muhammad Yahya without any compensation, under the pretext that the land for planting cassava is owned PTPN VII Business Unit Bunga Mayang where the defendant is employee PTPN VII Business Unit Bunga Mayang in Section land duty is to open and cultivate the lands that had been owned by PTPN VII Bunga Mayang Business Unit;

\footnotetext{
${ }^{13}$ Lilik Mulyadi, Putusan Hakim dalam Hukum Acara Pidana Indonesia, Bandung: Citra Aditya Bakti, (2014), p. 8

${ }^{14}$ Wirjono Projodikoro, Tindak Pidana Tertentu Di Indonesia, Bandung: Refika Aditama, (2012), p.58

${ }^{15}$ Andi Hamzah, Delik-Delik Tertentu di Dalam KUHP, Jakarta: Sinar Grafika, (2014), p.196.

${ }^{16}$ Ibid.
} 
That the destruction by the defendant against the cassava plant owned by Witness II: Haiyun bin Mursalin does not have a legal relationship with the land planted with cassava with civil law matters, because it is clear that cassava marred by the way bulldozed by the defendant is the property of Witness II: Haiyun bin Mursalin that has been planted itself long before the presence of civil disputes between Witness II: Haiyun bin Mursalin with PTPN VII Bunga Mayang Business Unit; That the disputed ownership of the land can not be used as an excuse to release the defendant on all charges; That of the description of the facts mentioned above, the defendant has been proven legally and convincingly guilty of committing a criminal offense as mentioned in the indictment One Attorney / Prosecutor General, so that the defendant must be punished commensurate with the error he had done"

Thus, law enforcement against the criminal acts of destruction of crops will arise. According to the judges of the Supreme Court by Decision No. 1909 K / Pid / 2010) using optical or viewpoint Agrarian Law to the principle of horizontal separation that holders of rights to land only control the extent of its surface only, while the building or anything inherent in the land of different rights with land ownership control the other parts.

\section{The Legal Protection of the Legitimate Land Owners Regarding the Use of Land by Unauthorized Parties}

Based on the issue of Criminal Law enforcement, the problem is related to the legal protection of legitimate landowners over the use of land by unauthorized parties. An example is in the case of PTPN VII Business Unit Bunga Mayang above, where PTPN VII Business Unit Bunga Mayang has a certificate of rights of exploitation of the National Land Agency (BPN) of the Republic of Indonesia, as the right base rightful owners, while the victim witness does not have the right base, However, the said witnesses have planted cassava on land owned by PTPN VII Bunga Mayang Business Unit. If such things are allowed, and there is no legal action for the rightful owners to the opposite of the other parties who use the land without their permission. Based on interviews with respondents namely Dr. Nikmah Rosidah. SH, M.H., An academician from Faculty of Law at the University of Lampung, states that landowners should get legal protection from the illegal actions namely that the other parties did land invasions such as by using Article 385 point 1 Criminal Code, which asserts that:

By a maximum imprisonment of four years shall be punished: any person who with the intention to unlawfully benefit himself or another, sells, exchanges or encumbers with mortgage an Indonesian right of use to land, or a building, work, planting or sowing on land on which Indonesian rights of use are exercised, knowing that another has Or shares the title thereto; The problem is, when using the said law, it does not meet the elements of a 
criminal offense if the offender only occupy and cultivate the land, but do not sell or transfer to another party. In addition, according to the respondents, the owner of land can use Law No. 51 PRP of 1960 on Prohibition to Using the Land without Obtaining the Permission from the Owner of the Land or the Authorized Person (Law. No 51 PRP/1960"), the Article 2 of the said law stated that the utilization of land without obtaining the permission from the owner of the land or the authorized person of the land, shall be construed as the prohibited act, and shall be penalized of imprisonment for the maximum time of 3 (three) months". By using this legal basis, hence the landowner can retain his rights and force to the legal process for another illegal party who occupy without the owner of the land became entangled as the criminal acts of destruction of crops under the Article 406 paragraph (1) Criminal Code.

\section{Conclusion}

\section{Conclusion}

Based on the above research, the research could be concluded as follows:

a. The law enforcement against the criminal acts of destruction of crops based on the judges of the Supreme Court Decision No. 1909 K / Pid / 2010, using the viewpoint of Agrarian Law to the principle of horizontal separation asset that the holders of rights to land only control the extent of its surface, while the building or anything inherent in the land have different ownership rights to its land. The criminal law enforcement using viewpoint of Law No. 5 Of 1960 Regarding The Basic Regulations On Agrarian Principles (UUPA) does not need to prove the ownership of the land between the two conflicting parties but to prove the owner of the destroyed crops. If the plant grows the property of the complainant party then the reported person will meet the elements as perpetrators of criminal acts in the Article 406 paragraph (1) of the Criminal Code.

b. By using the legal basis of the Law Number 51 PRP of 1960 on Prohibition to Using the Land without Obtaining the Permission from the Owner of the Land or the Authorized Person (the "Law No 51 PRP/1960"), landowners can maintain proprietary rights and submit the case to the legal process procedure, hence it does not need to happen that the crop destruction by the owner of the land will be entangled in the criminal law pursuant to the Article 406 paragraph (1) Criminal Code. 


\section{Suggestion}

a. The results revealed here is the need of improvement regarding the regulation of land and crops ownership which is regulated in the Civil Code as well as the Law No. 5 Of 1960 Regarding The Basic Regulations on Agrarian Principles (UUPA).

b. Based on the research, there is a need of socialization regarding the Law Number 51 PRP of 1960 on Prohibition to Using the Land without Obtaining the Permission from the Owner of the Land or the Authorized Person (Law No 51 PRP/1960), hence the landowner can retain his rights and force to the legal process for another illegal party that occupy without the owner of the land became entangled as the criminal acts of destruction of crops pursuant to the Article 406 paragraph (1) Criminal Code.

\section{Bibliography}

\section{A. Book}

Arief, Barda Nawawi. (2012). Tujuan dan Pedoman Pemidanaan. Semarang: Pustaka Magister.

Dewi, Erna. Sistem Peradilan Pidana Indonesia (Dinamika dan Perkembangan). Yogyakarta: Graha Ilmu.

Hamzah, Andi. (2014). Delik-Delik Tertentu di Dalam KUHP, Jakarta: Sinar Grafika.

Harsono, Boedi. (1997). Hukum Agraria Di Indonesia; Sejarah Dan Pembentukan Undang-Undang Pokok Agraria; Isi Dan Pelaksanaannya. Jakarta: Djembatan.

Harsono, Boedi. (2003). Hukum Agraria Indonesia. Jakarta: Djambatan.

Mulyadi, Lilik. (2004). Hukum Pidana, Krimonologi \& Victimologi. Jakarta: Djambatan.

Mulyadi, Lilik. (2014). Putusan Hakim dalam Hukum Acara Pidana Indonesia. Bandung: Citra Aditya Bakti.

Projodikoro, Wirjono. (2012). Tindak Pidana Tertentu Di Indonesia. Bandung: Refika Aditama.

Siswanto, Heni. (2013). Rekonstruksi Sistem Penegakan Hukum Pidana Menghadapi Kejahatan Perdagangan Orang. Semarang: Pustaka Magister.

Soepomo. (1964). Sejarah Politik Hukum Adat. Jakarta: Djambatan

Sumardjono, Maria S. (2008). Tanah dalam perspektif hak ekonomi, sosial, dan budaya. Jakarta: Kompas.

Sumardjono, Maria S.W. Kebijakan Pertanahan (Antara Regulasi dan Implementasi). Jakarta: Kompas, 


\section{B. Journal}

Tjong Tjo Djung, Eddy Rifai dan Eko Rahardjo, "Analisis Pemidanaan Terhadap Pelaku Tindak Pidana Perdagangan Orang”, Jurnal Praevia, 6 (2), (2012). 